\title{
Geochronology and Petrogenesis of Late Carboniferous Sanukitoids in Northern West Junggar, NW China
}

\author{
ZHiguO ZHANG ${ }^{1}$, XiJun LiU ${ }^{1}$, Yu SHI ${ }^{1}$ \\ ${ }^{1}$ College of Earth Sciences, Guilin University of Technology \\ 12 Jiangan Road, Guilin Guangxi, 541004, P.R. China
}

The sanukitoid is a kind of high-Mg andesites, distincted from normal andesites that typify arc magmatism in their elevated $\mathrm{MgO}$ contents and/or $\mathrm{Mg}^{\#}\left[=100^{*} \mathrm{Mg} /(\mathrm{Mg}+\mathrm{Fe})\right]$, which is special and rare mantle derived rock types that reserved in modern and Archena subduciton zones as well as accretionary orogenic belt. The Central Asian Orogenic Belt (CAOB) is a giant accretionary orogen and the most important area of Phanerozoic continental growth around the world. It is evolved through a long-lived orogeny involving multiple episodes of subductions and accretions marking a major phase of continental growth during the Paleozoic. The occurrence of sanukitoids in Hamutusi area between the Boshchekul-Chingiz arc and Zharma Saur arc in northern West Junggar of Northwestern China is of particular importance to a understanding of tectonic setting and evolution history of CAOB. We report the sanukitoids zircon $\mathrm{U}-\mathrm{Pb}$ age yielded crystallization age of $324.4 \pm 6.9 \mathrm{Ma}$ (MSWD=0.109), suggesting its formation during the Carboniferous..Geochemically, the sanukitoids are calcalkaline, enriched in $\mathrm{SiO}_{2} \quad(58.10-59.01 \mathrm{wt} . \%)$ and characterized by high $\mathrm{MgO}$ (6.09-6.99wt.\%) and $\mathrm{Mg}^{\#}$ (61 69 ), belong to the high-Mg andesite. Moreover, the sanukitoids are enriched in LILEs (e.g. K, Rb, Ba and U) and LREEs, but strongly depleted in HFSEs (e.g. Nb, Ta and Ti), consistent with the geochemical characteristics of subductionrelated magmas. They have low Sr contents (192 374 ppm), low $\mathrm{Sr} / \mathrm{Y}$ ratios (11 25) and high $\mathrm{Cr}(147 \sim 448 \mathrm{ppm})$ and $\mathrm{Ni}$ (29.11 119 ppm) concentrations similar to those of typical Cenozoic sanukitoids at the Sentouchi Volcanic Belt, SW Japan. The sanukitoids have $\varepsilon \mathrm{Nd}_{(t)}$ values ranging from -0.25 to +2.20 , indiate their mantle source is more enriched and contribution of subducted sedimmens melt. We suggest the Hamutusi sanukitoids are possibly derived from a depleted mantle source (or sources) mixing subducted sediments, which formed by the melting subducted sediments and subsequent melt-mantle mixing and interaction, which share the similar mechnism with those of sanukitoids from the Setouchi Volcalnic Belt, SW Japan. This study suggest that the West Junggar was still in a subduction setting in the Late Carboniferous. 